\title{
Sistema da dívida pública e a dependência da distribuição de recursos orçamentários da União: o caso dos municípios de pequeno e médio portes do Alto Vale do Itajaí (2010-2017)
}

\begin{abstract}
Valdir Alvim*
Mailon José Espindola**

\section{Resumo}

O objeto de investigação do artigo se constitui na repartição tributária das transferências correntes constitucionais obrigatórias entre a União, Estado de Santa Catarina e Municípios. Neste sentido, realiza estudo de caso na região do Alto Vale do Itajaí, visando compreender a situação crítica das finanças dos municípios de pequeno e médio portes, entre 2010 e 2017. O contexto abarca as crises econômicas recentes que elevam gastos e reduzem investimentos em Saúde, Educação e Assistência Social. Alinha-se o papel dos gestores públicos na ampliação dos esforços para aumento da arrecadação própria. Os resultados demostram a dependência orçamentária dos municípios, evidenciado através das transferências constitucionais insuficientes, diante da repartição de responsabilidades de recursos e gestão da $\mathrm{CF} / 88$, o que dificulta e onera a execução orçamentária, impacta negativamente nas políticas e serviços públicos ofertados aos munícipes.
\end{abstract}

Palavras-chave: dívida pública; orçamento público; pacto federativo.

\section{Public debt system and dependence on the distribution of budgetary resources in the Union: the case of small médium sized municipalities in the Alto Vale do Itajaí (2010-2017)}

\begin{abstract}
The object of investigation of the article is the tax breakdown of mandatory constitutional current transfers between the Union, State / SC and Municipalities. In this sense, it carries out a case study of the Alto Vale do Itajaí region sought to understand the critical financial situation of small and medium-sized municipalities between 2010 and 2017. The context encompasses recent economic crises that increase spending and reduce investments in Health, Education and Social Assistance. The role of public managers in aligning efforts to increase their own revenue is aligned. The results show the budgetary dependence of the municipalities, evidenced by the insufficient constitutional transfers, in view of the allocation of responsibilities for resources and management of the CF / 88, which makes budgetary execution difficult and burdens, negatively impacting public policies and services offered to citizens.
\end{abstract}

Keywords: public debt; public budget; federative pact.

JEL: H72

\footnotetext{
* Professor do Departamento de Economia e Relações Internacionais da Universidade Federal de Santa Catarina (UFSC) e membro do Núcleo de Estudos Sociopolítico do Sistema Financeiro (NESFI).E-mail: valdir.alvim@ufsc.br;

** Economista graduado pela Universidade Federal de Santa Catarina (UFSC) e assessor da Secretaria de Administração, Planejamento e Finanças da Prefeitura Municipal de Mirim Doce (SC). E-mail: maylon_je@hotmail.com
} 


\section{Introdução}

A descentralização e distribuição das receitas no Orçamento Geral da União (OGU) foram tratadas no contexto do pacto federativo cujo resultado foi a Constituição de 1988 (CF/88). A sétima carta magna da República brasileira estabelece como independentes e harmônicos os Poderes Legislativo, Executivo e Judiciário e conferiu status público de Ente federado aos governos municipais inserindo-os na estrutura federativa do Estado.

O Brasil criou um modelo "único no mundo" como um divisor de águas na história do país quando saiu do modelo dual instituindo a autonomia relativa do Município, estendendo-os a possibilidade de se organizar administrativa, política e financeiramente, expressão que indica a capacidade de autogoverno, autoadministração e auto-organização (MONTALVÃO, 2018).

Essa autonomia relativa e reconhecida função pública dos repasses orçamentários aos Municípios não são suficientes para atingir plenamente os objetivos de melhoria na gestão e custeio de Planos, Programas, Projetos e ações articuladas, principalmente em áreas sociais sensíveis tais como Saúde, Educação, Assistência Social e nos programas Estratégia Saúde da Família e o Programa Nacional de Alimentação Escolar. Isto é motivo suficiente para ampliar os questionamentos sobre os mecanismos fiscais adensados na concentração e na centralização tributária do pacto federativo de 1988, gerando insuficiências orçamentárias na medida em que os municípios foram elevados a condição de Ente Federativo.

Não nos parece sensato que recursos orçamentários insuficientes penalize duplamente os cidadãos contribuintes nos seus direitos sociais e constitucionais ao restringir o acesso aos serviços públicos de qualidade e necessários nessas áreas. Por isso não nos parece justo, nem do ponto de vista econômico nem do ponto de vista social, que caiba aos gestores públicos enfrentar os grandes desafios locais das demandas populacionais sem a devida suficiência nos repasses e geração de receitas próprias que eleve e melhore os controles fiscais.

Apesar da CF/88 ser considerada uma das "mais democráticas" dos processos constituintes sucessivos, eles não alteraram o histórico do centralismo existente realizados no Brasil. A centralização dos recursos do OGU diz respeito à concentração do poder na capacidade tributária da União, o que exige uma reforma tributária que corrija as desigualdades na repartição dos recursos orçamentários da União, o Distrito Federal, Estados subnacionais e Municípios. 
Ver-se-á, aqui, a problemática das enormes dificuldades encontradas pelos municípios catarinenses do Alto Vale do Itajaí dentro da crítica realidade orçamentária, cujos mecanismos de transferência afeta-os negativamente, principalmente os de pequeno e médio porte. Os recursos concentrados na União e repassados para os municípios a valores nominais, geram ainda mais consequências negativas para a elevação e deterioração das finanças públicas com a expansão da dívida pública e sérias dificuldades para os gestores municipais.

O plano de exposição está divido em cinco seções. A primeira seção está contida na introdução e institui a problemática da pesquisa e sua forma de investigação. A segunda parte apresenta a situação crítica da repartição desigual dos recursos orçamentários da União e dos Estados subnacionais, ao analisar o que se convencionou chamar de sistema da dívida pública, pela Auditoria Cidadã, nos esquemas de controle do pacto federativo com a instituição da LRF/2000 ao exigir condicionalidade de adimplência em obrigação financeira ou contratual. Na terceira seção evidencia-se os afeitos negativos fortes sobre a arrecadação dos tributos nos municípios no contexto das crises políticas e econômicas recentes, entre 2002 e 2007. Na quarta está demonstrado os efeitos dos desequilíbrios orçamentários no estudo de caso dos municípios de pequeno e médio do Alto Vale do Itajaí, situação que perdem parte da autonomia, geram receitas tributárias insuficientes e possuem considerável volume de recursos na dependência exclusiva das transferências correntes da União e do Estado/SC. Na quinta seção avalia-se os impactos negativos diante das restrições orçamentárias que afetaram as finanças públicas nos últimos anos. Destaca-se o papel dos gestores municipais na situação de desequilíbrios orçamentários e a busca de alternativas para corrigir desequilíbrios. As considerações finais demostram evidências acerca da ampliação da dependência dos municípios aos repasses de receitas orçamentárias através das transferências correntes da União e do Estado/SC, em proporções de comprometimento dos recursos disponíveis.

\section{Situação crítica e desigualdade na repartição dos recursos orçamentários da União}

Desde os anos 2000 o movimento social intitulado Auditoria Cidadã da Dívida Pública (ACDP) faz campanha pública para restringir a destinação de fluxos imensos de dinheiro público do OGU e elevado volume de recursos para pagamentos de juros à rentistas/especuladores. Desde então, nestes últimos vinte anos, a ACDP vem realizando 
duras críticas ao agravamento dos problemas nacionais relativos ao pacto federativo da $\mathrm{CF} / 88$.

A Auditoria é uma organização da sociedade civil e integra o movimento social e tem a colaboração, apoio e participação de grande número de cidadãos, entidades e instituições. As atividades da Auditoria marcam presença desde setembro de 2000 quando da realização da Campanha Jubileu Sul com o Plebiscito Popular sobre a Dívida Externa. A Campanha contou com inúmeras organizações sociais cobrindo 3.444 municípios brasileiros. Participaram da votação 6,03 milhões de cidadãos dos quais "mais de 95\% votaram NÃO à manutenção do Acordo com o FMI; NÃO à continuidade do pagamento da dívida externa sem a realização da auditoria prevista na Constituição Federal, e NÃO à destinação de grande parte dos recursos orçamentários aos especuladores".

A ACDP continua a busca pelos efeitos do pacto federativo produzidos pelos mecanismos do que se convencionou chamar de "sistema da dívida pública" na distribuição das receitas orçamentárias, previstas na $\mathrm{CF} / 88$. O conceito foi desenvolvido por Maria Lúcia Fatorelli, coordenadora nacional da ACDP, após 14 anos de investigação sobre o endividamento público na América Latina, Europa, África e particularmente no Brasil. O processo de endividamento ocorre quando se promove "contínua e crescente subtração de recursos públicos" ao invés deles servirem para dar suporte às políticas de financiamento dos direitos e necessidades sociais. O sistema da dívida corresponde ao "uso do endividamento público às avessas" em que os recursos são direcionados principalmente ao setor financeiro e privado (FATORELLI, 2014).

Este sistema de endividamento expõe a problemática das transferências constitucionais no esquema de repartição dos recursos tributários da União para Estados subnacionais e municípios. Apesar das transferências correntes não estarem diretamente vinculadas a determinadas despesas, a Lei de Responsabilidade Fiscal (LRF) estabelece limites quanto a sua destinação.

As principais limitações são aquelas em que estabelece indicadores mínimos de gastos em Educação e Saúde e máximo em gastos com Pessoal, por exemplo. Ao se analisar a regularidade da distribuição das despesas correntes constata-se que a Receita Disponível está concentrada no Tesouro da União e retém em média $56 \%$ dos recursos da repartição; os Estados subnacionais ficam 25\%; e os municípios com 19\%.

Estas despesas correntes são de classificação econômica na definição dos desequilíbrios da distribuição orçamentária, pois respondem ao princípio da inclusão, de 
todas as despesas relativas aos gastos com as obrigações de manutenção da máquina pública, incluindo aí despesas de pessoal e encargos, juros e encargos da dívida, e outras despesas correntes.

Entretanto, o destaque fica por conta das Despesas de Pessoal cujo limite de gastos é de no máximo 54\% das Receitas. Quanto a este limite destaca-se as evidências em que "o endividamento público não tem funcionado como instrumento de financiamento das necessidades coletivas", pois esquemas de perpetuação das dívidas são adensados por políticas de ajustes e reestruturação do Estado (FATORELLI, 2013, p. 3).

Nestes esquemas, o pacto do federalismo fiscal conserva ainda os traços fundamentais da arquitetura do plano original. No final das contas estes esquemas de endividamento consistindo em transferir enormes volumes de renda pública para financiamento das necessidades de pagamento de juros e amortizações das dívidas, afeta o perfil Dívida/PIB através de ajustes operados há décadas e seus efeitos fiscais e tributários deletérios comprometem as demais rubricas dos gastos sociais.

Estes efeitos tem significado, em primeiro lugar, na necessidade do Estado em elevar a arrecadação dos tributos por meio do consumo, dado o caráter regressivo destes impostos, transfere renda das comunidades vulneráveis dos mais pobres; Segundo, pela insuficiência na oferta ou ausência dos serviços públicos municipais tais como saúde, educação, assistência social, previdência, etc., prejudicando a população dos mais pobres e necessitados; Terceiro pela privatização, processo da desestatização em que transfere bens e serviços públicos para a esfera privada da sociedade civil com a transferência de parte dos serviços públicos e patrimônio; E quarto, consequências negativas para a sociedade em geral e a ecologia em particular, causando danos muitas vezes irreparáveis ao meio ambiente pela exploração ilimitada das riquezas naturais (FATORELLI, 2013, p. 3).

O Gráfico 1 demonstra que 40,66\% dos $\mathrm{R} \$ 2,6$ trilhões do orçamento executado foram para pagamento de juros e amortizações da dívida em 2018, e ficou acima dos 39,7\% de 2017. A Previdência Social com 24,48\% participa do bolo na segunda posição. Outra realidade dos fatos expõe claramente os esquemas da política da centralização, como a desigual distribuição dos recursos orçamentários através das Receitas de Transferências Correntes, realizadas através de repasses pela União e representam a terceira maior fatia da pizza dos gastos com $\mathrm{R} \$ 257,38$ bilhões, $9,82 \%$ do realizado. 
Estes mecanismos geram enormes benefícios ao desenvolvimento do setor financeiro, em detrimento do financiamento público das necessidades sociais das populações locais.

Gráfico 1: Orçamento Geral da União: pagamento executado de juros e amortizações da dívida em 2018

\section{Orçamento Federal Executado (Pago) em 2018 = R\$ 2,621 TRILHÕES}

O valor previsto para 2018 havia sido R\$ 3,527 Trilhōes, diferença a ser investigada

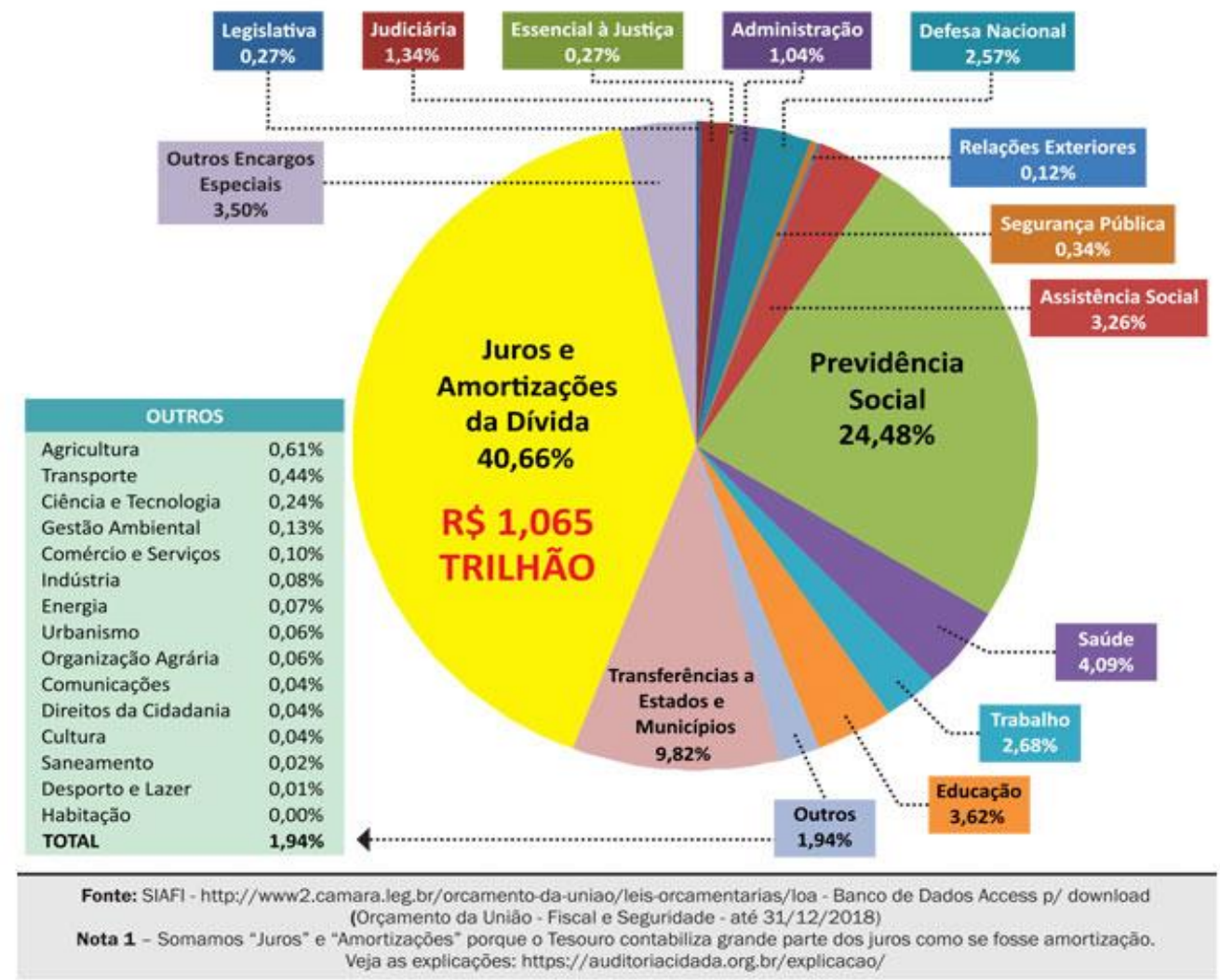

Fonte: Auditoria Cidadã da Dívida, 2019.

Cria-se assim, por si só, restrições fiscais e tributárias aos Estados subnacionais e Municípios na medida em que buscam atender as necessidades de serviços públicos básicos dos habitantes locais, devido ao aumento das responsabilidades constitucionais transferidas aos municípios pela $\mathrm{CF} / 88$.

Neste caso, a Confederação Nacional dos Municípios (CNM) relata que o grau de dependência revela que mais de $80 \%$ dos recursos orçamentários são de fontes externas à arrecadação em 70\% dos municípios brasileiros. A CNM estima que o Fundo de Participação dos Municípios (FPM) representa 60\% das Receitas de Transferências Correntes, 
Constitucionais e/ou Voluntárias, ou seja, apenas R\$ 154,428 bilhões do realizado em 2018 para ser distribuído aos mais de 211 milhões de habitantes em 5.570 municípios (5.568 mais o distrito insular de Fernando de Noronha e o Distrito Federal). A CNM relata que o volume do FPM encolheu 2,3\% em 2015, já deflacionado, e tende a cair em 2019 em torno de 10\% [anterior tendência a crise pandêmica do Covid19].

Nas transferências aos Estados subnacionais destacam-se parcelas do Imposto sobre Propriedade de Veículo Automotor (IPVA); Imposto sobre Circulação de Mercadorias e Serviços (ICMS); e Transferências Fundo a Fundo, que dispensam a celebração de convênios e a colocam como instrumento de descentralização de recursos, disciplinados em leis específicas cuja característica principal é realizar o "repasse direto de recursos provenientes dos fundos da esfera federal para fundos da esfera estadual, municipal e do Distrito Federal" (CANZIAN, 2019).

O documento da Política Nacional de Assistência Social (PNAS) considera que os destinatários das políticas são os segmentos populacionais "involuntariamente excluídos das políticas sociais básicas", e os fundos que a compõem operam a modalidade de transferência, a partir do Fundo Nacional da Assistência Social (FNAS) e o Fundo Nacional de Saúde (FNS).

As disposições normativas que disciplinam essas transferências constituem a Lei n. ${ }^{\circ}$ 9.604, de 5 de fevereiro de 1998 e o Decreto n. ${ }^{\circ}$ 2.529, de 25 de março de 1998. Esse último regulamenta a Norma Operacional Básica da Assistência Social (NOB-AS) que define as "estratégias e movimentos mais operacionais que possibilitem o avanço em direção ao sistema inscrito na lei".

Em outros termos, define as "competências dos órgãos gestores e das instâncias de negociação e controle social, fluxos e requisitos para o processo de habilitação, mecanismos e critérios" que levam ao repasse dos recursos do FNAS para os fundos estaduais, do Distrito Federal e municipais de Assistências Social.

Assim, os recursos destinados pela União aos Estados, ao Distrito Federal e municípios para operacionalização dos serviços assistenciais "visam suprir as demandas referentes à manutenção de ações de atendimento às crianças de zero a seis anos, aos idosos e às pessoas portadoras de deficiências" (GOMES, 2013, p. 3).

Já, Outras Receitas Correntes referem-se a indenizações, restituições e outras receitas que não se classificam nas outras categorias. As Receitas Correntes Tributárias Próprias ou Outras Receitas, restantes, são as arrecadadas pelos municípios e ficam integralmente no 
Tesouro municipal. As principais receitas tributárias municipais são: o Imposto sobre Produtos Industrializados (IPTU); o Imposto sobre Transmissão de Bens Imóveis (ITBI); o Imposto Sobre Serviços de Qualquer Natureza (ISQN); Taxas de Licença e de Localização (TLL), entre outros. Com isso posto a FECAM (2017) insere no debate uma proposta para melhoria do equilíbrio na repartição tributária. Pela proposta, a União reteria do total do arrecadado cerca de $45 \%$, restaria aos municípios recolherem $30 \%$ e Estados subnacionais $\operatorname{com} 25 \%$.

Desta forma distribuindo, deve-se melhorar significativamente a distribuição das receitas correntes e as receitas de capital, expandindo o volume de recursos necessários para financiar os serviços nos municípios.

Por fim, têm-se as Receitas de Capital provenientes de operações de crédito, alienação de bens e convênios tanto com a União quanto dos Estados da federação. As Receitas de Capital vêm para ser aplicadas em objetos pré-definidos, exceto quando se fala em alienação de bens que o gestor pode determinar - no que irá aplicar depois do recurso estar no Caixa, desde que relacionado a algum bem com durabilidade superior a dois anos. Estas receitas só podem ser utilizadas para adquirir ou construir bens, como obras, máquinas e equipamentos, não são contas Correntes e não computam ao Caixa das prefeituras periodicamente, uma vez que estão condicionadas a firmação de convênios com governos, estaduais e Federal, pelo fato de concentrarem parte maior dos recursos orçamentários. A concentração dos recursos orçamentários na União se eleva proporcionalmente de 51\%, para 59\%, em 1991 e 2015, enquanto os municípios tiveram redução de 19\% para $16 \%$ no total. O poder de investimento dos municípios foi imensamente prejudicado pela redução da participação e pelo sucedâneo das crises econômicas e políticas (FECAM, 2017).

As medidas tomadas no contexto das crises pelos gestores municipais são afetadas frequentemente pelos cortes no orçamento, viabilizado para "fechar as contas" do Município. Novas responsabilidades constitucionais trouxeram consequências negativas ao elevar de forma drástica, e insustentável, as despesas orçamentárias diante das insuficiências, às sempre crescentes e complexas demandas da população, principalmente aos que vivem nos municípios de pequeno e médio porte. Isto, por si só, gera insuficiência de recursos, paralela situação anterior a $\mathrm{CF} / 88$ quando cabia aos Municípios apenas os serviços "mais próximos" das necessidades da população, como transporte público; ensino pré-escolar e de $1^{\mathbf{0}}$ grau; saúde preventiva; uso do solo urbano e conservação do patrimônio cultural. 
Diante das insuficiências orçamentárias e dos parcos recursos disponíveis, coube ao gestor municipal tornar os gastos públicos mais eficientes, tomar decisões tempestivas e praticar atos "heroicos" visando gastar e investir melhor os recursos disponíveis para execução orçamentária, ou seja, os gestores terão sempre que "fazer mais com menos" (ESPÍNDOLA, 2017).

Entretanto, ao longo do período 2002 e 2007, no governo Lula (2003/2010) houve uma pequena redistribuição na repartição orçamentária. A participação relativa da União reduziu-se em nove pontos percentuais considerando 2002 (79,0\%) e 2007 (70,0\%); os Estados subnacionais ampliaram de $16 \%$ para $19 \%$ a participação, enquanto os Municípios ampliaram sua participação de $4 \%$ para $11 \%$, respectivamente, o que permitiu minimizar certos desequilíbrios nas despesas com receitas (BRASIL, 2018b).

\section{Repartição orçamentária e a descentralização tributária entre 2002 e 2007}

Fica claro na análise até aqui, que desde a $\mathrm{CF} / 88$ as responsabilidades dos municípios aumentaram muito, porém, mesmo com a instituição da LRF no ano de 2000, a destinação dos recursos não se alterou de forma significativa.

Nestes termos, ocorre que o cálculo diferencial no aumento das responsabilidades foi maior que o diferencial da expansão nas receitas, e dessa forma os municípios ficaram ainda mais dependentes dos repasses da União e dos Estados. Uma questão de vital importância para compreender a situação de dependência, tal qual um "Ente subalterno" à União, é o seu contrário, a não-dependência, com equivalência e não subalterno, elevado ao status de "Ente federativo" para ter maior autonomia tributária, política, administrativa e financeira.

Ocorre que na prática do cotidiano, mesmo tendo autonomia para criar leis orgânicas na constituição municipal, organizar administração local própria, legislar sobre assuntos de seu próprio interesse e arrecadar tributos, os municípios ainda estarão sujeitos a seguir o modelo de forma centralizada.

Pelos preceitos constitucionais de 1988 os municípios têm autonomia para tributar os seguintes impostos e taxas: Imposto Predial e Territorial Urbano (IPTU); Imposto sobre Transmissão Intervivos de Bens Imóveis (ITBI); e Imposto sobre Serviços de Qualquer Natureza (ISQN). Os municípios têm autonomia para tributar estes impostos, mas recebem 
certa quantia proporcional dos impostos recolhidos nas esferas Federal e dos Estados subnacionais.

Destes recolhimentos da União o percentual de $22,5 \%$ recai sobre a partição do Imposto de Renda (IR) e do Imposto sobre Produtos Industrializados (IPI). Dos impostos estaduais, 25\% recai sobre o Imposto Circulação de Mercadorias e Serviços (ICMS), e 50\% do Imposto sobre a Propriedade de Veículos Automotores (IPVA) (VEDANA, 2002, p. 205).

Uma questão de relevância fundamental para todos os cidadãos contribuintes, consiste em saber da eficácia das políticas públicas, se as demandas populares estão sendo bem atendidas e se os gastos com serviços públicos atendem a população, com eficiência.

Enfim, é no município que as pessoas residem e vivem, e o empoderamento do cidadão contribuinte depende da informação e da distância da base tributária. Assim como os Senadores representam seus Estados e os Deputados representam diretamente o povo, as prefeituras não possuem representantes institucionais no Congresso Nacional. Ainda assim os municípios não conseguirão viabilizar orçamento que fuja às regras estabelecidas na União federativa, dado que não possuem representantes diretos no Congresso e para viabilizar definição de gastos e investimentos de interesse local, acabam dependendo em muito destas representações político-partidárias, além de não possuírem autonomia financeira, o que os mantém dependentes das políticas dos Estados e da União (ESPÍNDOLA, 2017).

Cabe assim aos municípios certas responsabilidades proporcionais em comum (entre parênteses) sobre as políticas públicas nos seguintes serviços: transporte público e urbano/trânsito; ensino infantil e fundamental; saúde (Estados); assistência social; uso do solo urbano; conservação do patrimônio cultural; proteção dos recursos naturais e do meio ambiente (Estados); desenvolvimento urbano; planejamento regional e dos recursos naturais (Estados/União); agricultura (Estados); habitação (Estados); saneamento básico (Estado); programas de emprego e renda (Estados/União); telefonia/energia elétrica; água e saneamento rural (Estados) (VEDANA, 2002, p. 206).

As crises políticas e econômicas recentes têm provocado afeitos negativos fortes sobre a arrecadação dos tributos, resultando numa considerável diminuição das receitas, não obstante a inflação corroer o poder de compra dos orçamentos, reduz consequentemente os repasses aos municípios e Estados subnacionais.

Entretanto, o debate sobre a descentralização política e repartição dos tributos estende-se desde a Constituição de 1946 e só ganhou relevo e magnitude recentemente com 
a $\mathrm{CF} / 88$. Os artigos $1^{\circ}$ e $18^{\circ}$ consagram ao município uma pequena vitória parcial ao ser elevado à categoria de Ente Federado. Entretanto, a repartição dos recursos determinados vem sendo descaracterizados nas nuances da reorganização do sistema tributário nacional, na medida em que se prioriza a arrecadação de tributos não suscetíveis de repartição entre os demais entes federativos.

Assim, as repartições tributárias necessitam ser repactuadas constantemente para garantir recursos à adequada execução dos serviços públicos municipais. As dificuldades financeiras são visíveis e inquestionáveis, e apontam para o cenário da necessidade de uma nova delimitação do pacto federativo para os municípios.

Para se ter ideia, houve grande deterioração nos repasses do Fundo de Participação Municipal (FPM) devido a recomposição dos recursos federais com este tipo de tributo, não passíveis de repartição, apesar de corresponder a uma parcela pequena da arrecadação dos municípios. Isso indica que houve uma queda da arrecadação frente ao aumento das demandas, além do comprometimento dos recursos com folha de pagamento de pessoal e o custeio aos programas federais.

\section{Os desequilíbrios orçamentários: caso dos municípios do Alto Vale do Itajaí}

Representando a cultura do associativismo, tão presente em Santa Catarina, os municípios se articulam junto a Associação de Municípios do Alto Vale do Itajaí (AMAVI) para enfrentar cenários de desequilíbrios e encontrar alternativas dentro das limitações locais. No caso em tela, os municípios do Alto Vale apresentaram perda da capacidade de investimento, pois o volume de recursos demandados cresceu progressivamente, não "sobrando" muito para investir.

A dependência das transferências constitucionais faz com que qualquer alteração, como em momentos de crise econômica, resulte em forte impacto para os municípios, seja na regulamentação da cobrança dos tributos ou do volume arrecadado. Por exemplo, atos praticados pela União de desoneração fiscal do Imposto Sobre Produtos Industrializados (IPI), e pelas políticas dos Estados, reduziram a arrecadação municipal.

Outro fator agravante foi a criação de mais obrigações sem a devida contrapartida orçamentária, que onera as finanças municipais tem implicações na LRF/2000, e outras Leis unilaterais. Nesse sentido, o FPM é um exemplo da descentralização política e financeira 
vigente no Brasil. Esses recursos são creditados nos Caixas dos Municípios a cada dez dias, sem vinculação específica, devendo o gestor local decidir como utilizá-los, não podendo ser contingenciado. No entanto, a LRF obriga a utilização dos recursos orçamentários de pelo menos $25 \%$ investidos em Educação e $15 \%$ com Saúde, não podendo utilizar mais do que 54\% do total com gastos de Pessoal (ESPINDOLA, 2017).

Assim, o governo da União e seus gestores necessitam contratar recursos extraordinários para financiar os gastos e/ou reduzi-los. O que se tem percebido no setor público do Brasil, é que os resultados das políticas de austeridade fiscal têm apresentado comportamento redistributivo interno dos recursos orçamentários, importando na expansão do endividamento. Os munícipios de pequeno e médio porte perdem parte da autonomia, geram receitas tributárias insuficientes, e comprometem recursos orçamentários na dependência exclusiva das transferências correntes da União, através dos mecanismos do sistema da dívida pública.

Este sistema da dívida é operado então tendo como fonte de receitas o sistema tributário, e a atual realidade fiscal, explícita no presente debate, dá a medida dos recursos insuficientes e existência de déficits. A tributação operada há décadas na gestão orçamentária tornou-se negócio institucional especializado, dada regularidade das exigências de mecanismos financeiros poderosos, como o mecanismo das elevadas taxas de juros. Isto causa expansão da dívida mobiliária que financia o déficit público, como se fossem ajustes estruturais de rigidez fiscal que controla a expansão corrente da relação Dívida/PIB. ${ }^{1}$

Em 2015, dadas receitas acumuladas e analisadas dos municípios do Alto Vale do Itajaí, o índice médio de gastos chegou a 52,6\%, sendo que quando atinge 51,3\%, os municípios são obrigados a tomarem medidas para reduzi-lo, sob a pena de sanções, conforme artigos 19 a 23 da LRF/2000.

Os municípios analisados gastaram em média 29,3\% com Educação, quando lhes é obrigado a gastar no mínimo 25\%; em Saúde os gastos somaram 18,2\%, aonde o mínimo é 15,0\%. Nos limites desta distribuição, os municípios absorvem cada vez mais obrigações, sem a contrapartida de recursos necessários para fazer frente à expansão das demandas sociais.

\footnotetext{
${ }^{1}$ A relação Dívida/PIB é tratada de modo similar por organismos internacionais e/ou multilaterais nos diversos continentes, tendo seus custos de circulação transferidos por operações de crédito e/ou da emissão de títulos públicos com elevadas taxas de juros, polpudas comissões aos operadores, elevação dos gastos com tarifas e outros gastos de forma indireta para a sociedade.
} 
Esta classificação expõe na realidade as ditas condicionalidades para as despesas correntes, aquelas que não contribuem de forma direta para a formação ou aquisição de um bem de capital público, o que permite indagar sobre "o que" será adquirido e "qual" o efeito econômico da realização da despesa.

Os direitos sociais do cidadão são dispositivos legais que permitem condicionar o controle e a destinação dos recursos do OGU. Isto se dá através das garantias da CF/88 para a satisfação das necessidades da população, resultando ampliação do lado dos gastos com a seguridade social, tendo priorizado áreas e temas da educação, saúde, alimentação, trabalho, moradia, lazer, segurança, previdência social, proteção à maternidade e à infância, assistência aos desamparados etc. (BRASIL, 2002).

A Constituição de 1988, ao criar bases legais para desenvolvimento de um novo "marco civilizatório" para o Brasil recepcionou os direitos sociais em seu Artigo $6^{\circ}$ como direitos fundamentais, constituindo-se regras próprias para o destino vinculado dos recursos orçamentários, com proporções adequadas para transferência e financiamento dos direitos sociais.

A análise da situação crítica demostra queda proporcional das transferências constitucionais aos municípios, que se orienta assim pela expansão, cobrança e fiscalização dos tributos locais.

Entretanto, este novo marco civilizatório foi afetado negativamente pelas políticas de austeridade fiscal, que se utiliza de provimentos para sustentar as obrigações financeiras da União, dos Estados subnacionais e dos municípios.

A austeridade fiscal é considerada problemática na medida em que parte substantiva dos recursos destinados aos direitos sociais são redistribuídos para outras rubricas através de mecanismos ligados ao sistema da dívida pública, operados através: da regularidade altista das taxas de juros na história recente, financiamentos e expansão da dívida mobiliária, metas de superávit primário para reduzir a relação Dívida/PIB, metas de inflação como regime de controle de preços, e para arrebatar, controles da política cambial minimizando efeitos negativos na Balança de Pagamentos.

Podemos observar aqui, que as despesas correntes com a dívida pública possuem vínculos diretos com pagamento prioritário aos beneficiários de juros e amortizações. Assim, para fins fiscais a dívida, consolidada ou fundada, corresponde ao montante total das 
obrigações financeiras das dívidas Mobiliária e Contratual, apurado sem duplicidade (BRASIL, 2018). ${ }^{2}$

A Dívida Mobiliária Federal (DMF) é a representada por títulos emitidos pela respectiva esfera de Governo e a Contratual (DMC) é aquela realizada a partir de empréstimos e financiamentos internos e externos. Ela envolve o refinanciamento da dívida pública mobiliária de Estados e Municípios junto ao Governo Federal, seu parcelamento e renegociação, além das obrigações financeiras e das operações de crédito assumidas em virtude de contratos de Parceria Público-Privada (PPP) registradas no passivo patrimonial (BRASIL, 2018a).

Para garantia constitucional dos gastos relativos a uma obrigação financeira no âmbito da dívida mobiliária e contratual, cabe destacar que, uma vez enquadrada no conceito de Dívida Consolidada, a obrigação financeira não perderá essa característica pelo simples decurso do tempo. O montante da dívida contratual será reduzido somente quando houver o pagamento dessas obrigações. $\mathrm{O}$ empenho, a liquidação ou a inscrição de uma dívida em restos a pagar também não interferem na variação do montante da dívida consolidada de um ente federado.

Criada na era Fernando Henrique (FHC), a LRF no seu Art. 29, IV, corresponde aos esquemas de controle do pacto federativo ao exigir condicionalidade na concessão de garantia como compromisso econômico-político para a "obrigatoriedade" da "adimplência de obrigação" financeira ou contratual assumida por Ente da Federação, ou entidade a ele vinculada.

\section{Os gestores municipais e os desequilíbrios orçamentários}

Por não ter condições de produção de valor econômico que garanta sua autonomia tributária, os municípios de pequeno e médio portes dependem quase exclusivamente da repartição de recursos, maneira desigual de transferências dos recursos tributários, que afeta diretamente a qualidade dos direitos sociais e deteriora as instituições e a cidadania. Expor

\footnotetext{
${ }^{2}$ Excluídas: (... LRF, art. 30, § 2º e Resolução n ${ }^{\circ}$ 40/2001, do SF, art. $1^{\circ}$, $\S 1^{\text {o }}$, inciso V. 5 LRF, art. 29, inciso I e $\S 3^{\circ}$. Resolução $n^{\circ} 40 / 2001$, do SF, art. $1^{\circ} \S 1^{\circ}$ inciso III. 6 LRF, art. 30, $\S 7^{\circ}$ e Resolução $n^{\circ} 43 / 2001$, do SF, art. $2^{\circ}$, inciso III. Constituição Federal de 1988, art. 100, § 5. LRF, art. 29, § $1^{\circ}$. obrigações entre órgãos da administração direta e entre estes e as entidades da administração indireta),
} 
isso significa observar crescente dependência das transferências correntes da União por parte dos municípios de pequeno e médio portes.

Segundo a FECAM (2017), como visto, os municípios de Santa Catarina apresentam alto grau de dependência das receitas de transferências constitucionais e voluntárias. Entre 2006 e 2015, a média das receitas próprias dos 28 municípios ao Alto Vale do Itajaí analisados representou $12,4 \%$ do total das Receitas, ao passo que $87,6 \%$ eram oriundos de repasses do Estado de Santa Catarina e da União.

Diante das dificuldades geradas pela distribuição desigual, ao avaliar os impactos negativos diante das restrições orçamentárias que afetaram as finanças públicas ao longo desses últimos anos, coube aos gestores orçamentários municipais enfrentar os novos desafios e buscar alternativas para corrigir desequilíbrios das receitas correntes, líquida, das despesas com serviços e dos investimentos em obras públicas.

O resumo no Gráfico 2 demonstra a participação das principais fontes de receitas nos municípios do Alto Vale do Itajaí, em relação ao total, elaborada para o período entre 2001 e 2017. As cinco fontes de receitas elencadas correspondem a 98,0\% do total das receitas acumuladas nos municípios do Alto Vale do Itajaí: o FPM é a maior fonte, especialmente dos municípios de pequeno porte e corresponde, em média, a 37,5\% dos repasses aos municípios; em seguida, vem o ICMS com 28,0\%; o Fundo de Manutenção e Desenvolvimento da Educação Básica e de Valorização dos Profissionais da Educação (FUNDEB) com 15,2\%; Arrecadação Tributos Locais (ATL) com 13,21\%, e o IPVA com $4,1 \%$.

Gráfico 2: Participação das principais fontes de receitas nos municípios do Alto Vale do Itajaí, em relação ao total (2001-2017)

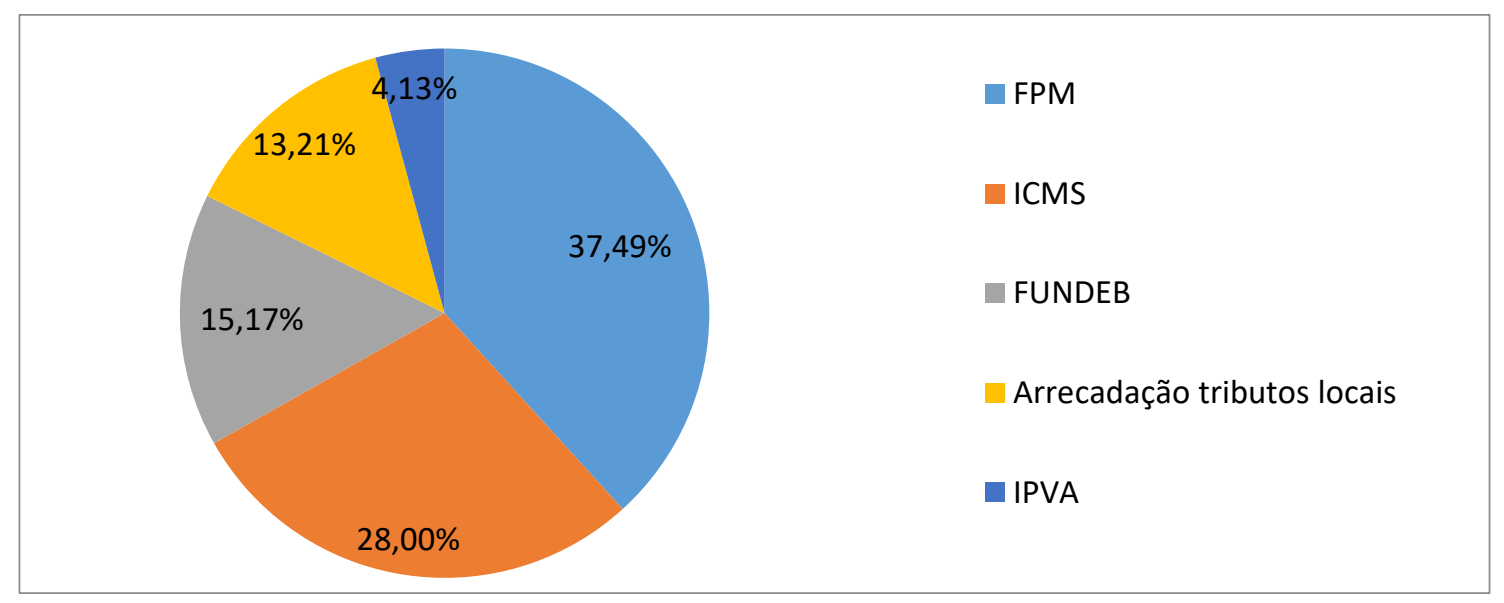

Fonte: Tribunal de Contas do Estado (TCE/SC), 2018 - Elaboração: Autores 
Quanto às receitas correntes vamos observar, aqui, que os municípios catarinenses buscam ter maior acesso aos recursos tributários do Tesouro para ampliar a participação na distribuição dos repasses orçamentários. O resultado não poderia ser outro. No lado das despesas vem os problemáticos cortes na folha de pagamentos com redução proporcional de pessoal não efetivo e contratado. Em seguida, a redução dos investimentos em obras e serviços públicos por falta recursos e pessoal, em detrimento da manutenção de obras e serviços públicos à população.

É nítido que os municípios ao Alto Vale do Itajaí possuem em média uma grande dependência de repasses dos governos federal e estadual, os indicadores demostram que os municípios possuem uma forte dependência, com poucas exceções. Por outro lado, pode identificar forte centralização nas esferas estaduais, e principalmente nacional, em detrimento do Ente municipal.

Os repasses brutos do período analisado foram somados e divididos com o total dos repasses, ano a ano, e a média calculada posteriormente. Assim, expressa o percentual de participação na receita total das principais fontes, e por se tratar de uma média, não significa que o fenômeno ocorre em todos os municípios exatamente dessa forma.

O fato do FPM possuir magnitude significativa e não poder ser contingenciado se constitui em importante fonte de receita para os municípios, principalmente aos de pequeno porte que compõem a maioria da região do Alto Vale. Os repasses são sazonais e ocorrem a cada dez dias e não há vinculação específica para aplicação, ficando a cargo dos gestores seu uso mais adequado.

A sazonalidade ocorre devido ao recebimento desigual dos tributos. O FPM é composto por dois impostos, IR e IPI, de repasse desigual entre os meses e de grande oscilação durante o ano. Essa situação traz dificuldades para o planejamento dos gestores. Isso quer dizer que em um mês o repasse de FPM pode ser elevado, mas no mês seguinte esse repasse pode ser menor. Nos Gráficos 3 e 4 observa-se a oscilação sistematizada do repasse do FPM. 
Gráfico 3: Sazonalidade dos repasses do FPM: municípios do Alto Vale do Itajaí - 20012017 (em valores nominais)

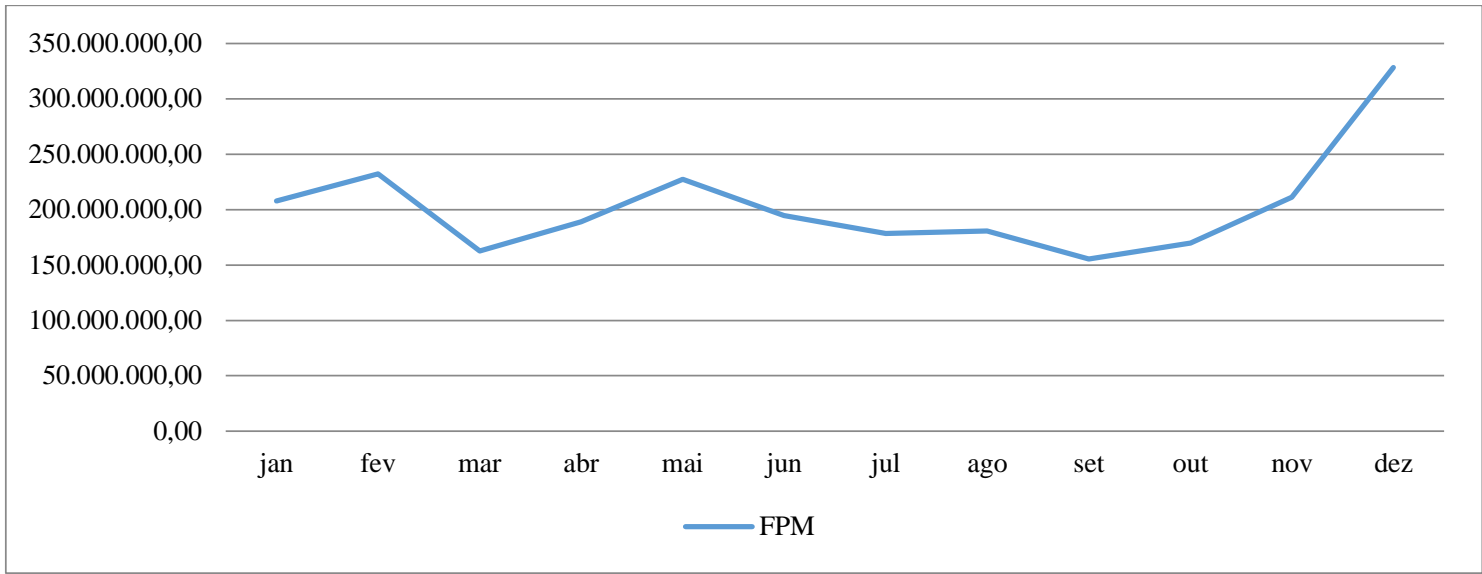

Fonte: FECAM, 2018 - Elaboração: Autores

Nos meses de março, abril, junho, julho, agosto, setembro e outubro os repasses ficam abaixo da média observada no mês de janeiro. Nos meses de fevereiro, maio, novembro e dezembro o repasse supera a média de janeiro.

O Gráfico 4 mostra o somatório dos valores nominais mês a mês dos repasses do FPM aos 28 municípios, entre 2001 e 2017. Vê-se que os municípios, em geral, passam por grandes dificuldades no segundo semestre de cada exercício. Nos gráficos anteriores observa-se que são nesses meses que o repasse do FPM apresenta maior diminuição, sendo em média, o mês de setembro o pior mês do ano. Em contrapartida, o mês de dezembro apresenta forte crescimento no volume dos repasses.

Gráfico 4: Repasses mensais do FPM: municípios do Alto Vale do Itajaí - 2001-2017 (jan = $1,00)$

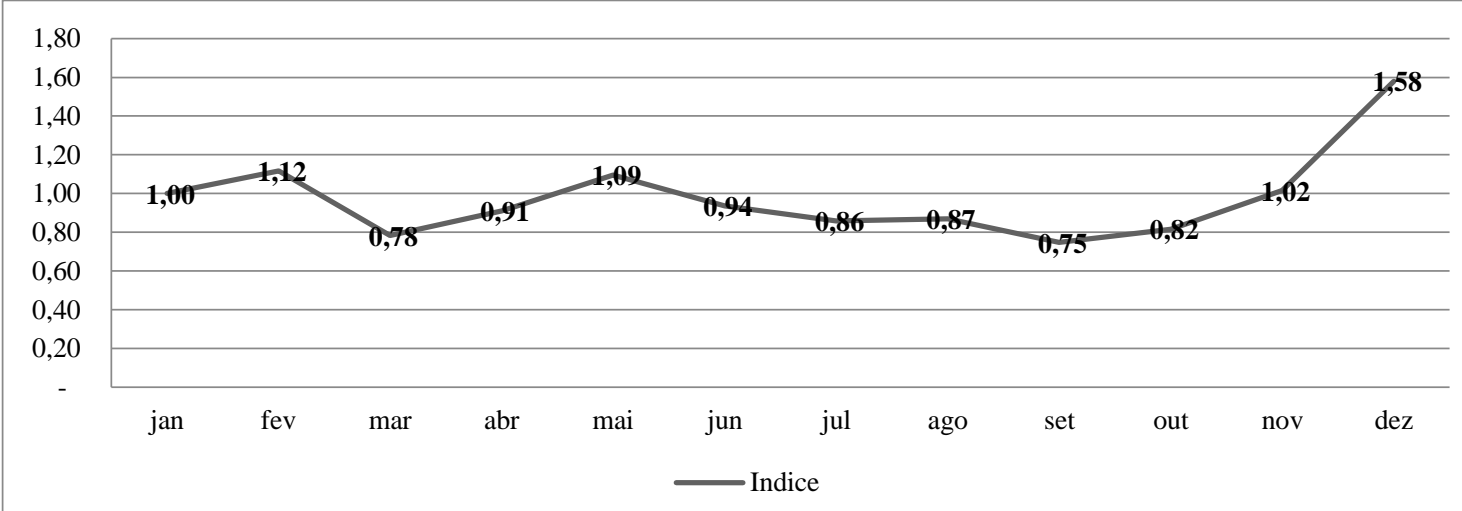

Fonte: FECAM, 2018 - Elaboração: Autores 
Vale a pena ressaltar que no mês de dezembro, além dos repasses decenais que aumentam devido ao crescimento da atividade econômica natural de final de ano, os repasses do FPM são complementados por uma parcela extra de FPM na ordem de 1,0\%, conforme determina a emenda Constitucional $\mathrm{n}^{\circ}$ 55, de 20 de setembro de 2007, o que contribui para o forte crescimento nos repasses no mês.

Ressalta-se, também, que é no mês de dezembro que muitos municípios pagam o décimo terceiro salário. Nesse contexto, o acréscimo de 1\% no FPM é absorvido pela despesa com pessoal relacionada ao décimo terceiro. O Gráfico 5 apresenta a evolução dos repasses do FPM acumulado nos 28 municípios e deflacionados a valores de 2001.

O somatório dos repasses do FPM aos municípios mostra que entre 2003 e 2008 no governo Lula (I e II) os repasses do FPM tiveram forte crescimento real graças ao cenário internacional favorável, aumento dos preços internacionais das commodities, entre outros. $\mathrm{O}$ ritmo de crescimento foi quebrado devido à crise econômica internacional de 2008.

Gráfico 5: Evolução dos repasses anuais do FPM: municípios do Alto Vale do Itajaí - 20012017 (valores de 2001)

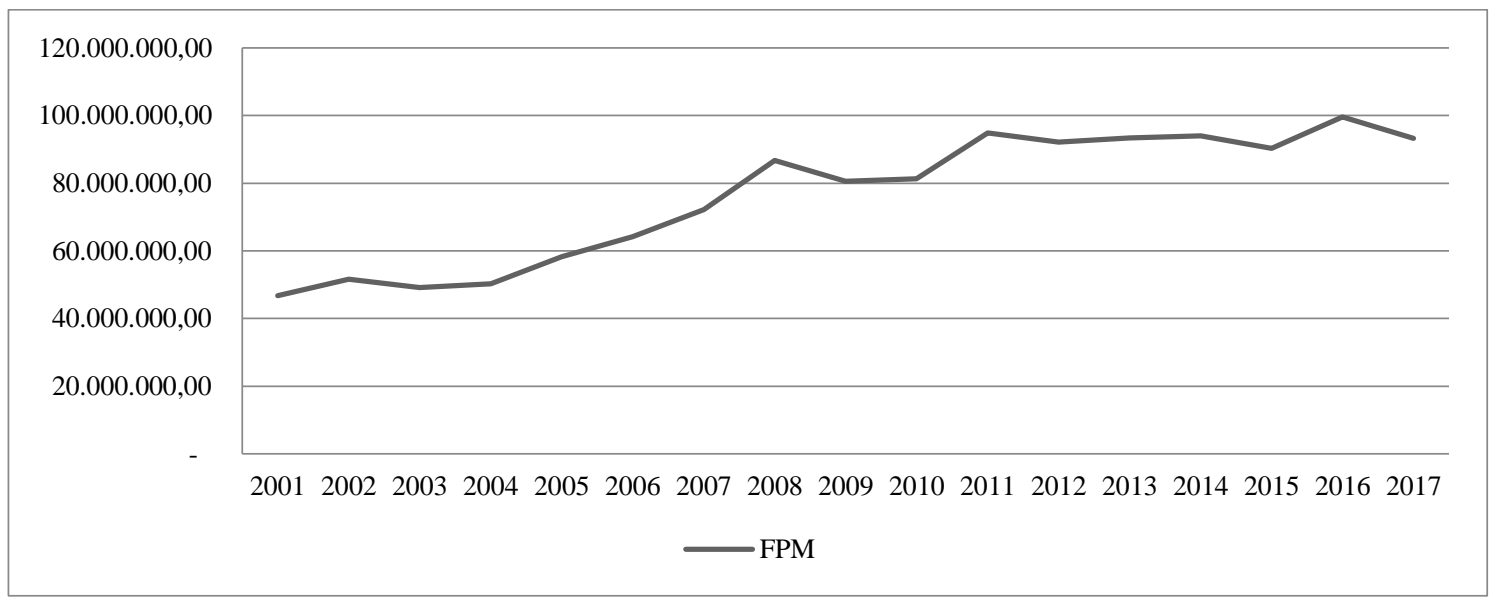

Fonte: FECAM, 2018 - Elaboração: Autores

Entretanto, o FPM de 2002 a 2003 reflete a diminuição dos quatro períodos anteriores como reflexo da crise asiática de 1998. Entre 2009 e 2010 o descenso ocorre devido à crise do subprime com o "estouro" da bolha imobiliária nos Estados Unidos entre 2007 e 2008, e desastrosa para a economia mundial. No governo Dilma, a queda se deu a partir de $2012 \mathrm{em}$ função das políticas de desonerações fiscais da linha branca e na retração na economia nacional, reflexo ainda da crise de 2007-08. Em 2015, com o impeachment da Presidenta 
Dilma houve diminuição das atividades econômicas e consequentemente da arrecadação e os repasses do FPM resultaram negativo.

No governo de Michel Temer o exercício de 2016 teve repasses positivamente breves, muito em função da repatriação dos recursos provenientes da operação Lava Jato. Destaca-se seu último pico em 2011, desconsiderando a parcela extra do FPM proveniente da repatriação e deflacionados a valores de 2001, os repasses do FPM diminuíram em função da queda na arrecadação e inflação em alta, expressando forte queda em termos reais em 2012, oscilando pouco até 2016 com perdas reais.

No geral, os repasses do FPM aumentaram no período considerando a inflação. Contudo, questiona-se se esse aumento não foi acompanhado de aumento das despesas devido aos incrementos das responsabilidades e demandas absorvidas pelos municípios, como se observa através de seus gastos totais executados.

Gráfico 6: Evolução dos repasses anuais do FPM: municípios do Alto Vale do Itajaí entre 2001 e 2017 - desconsiderando recursos da repatriação (valores de 2001)

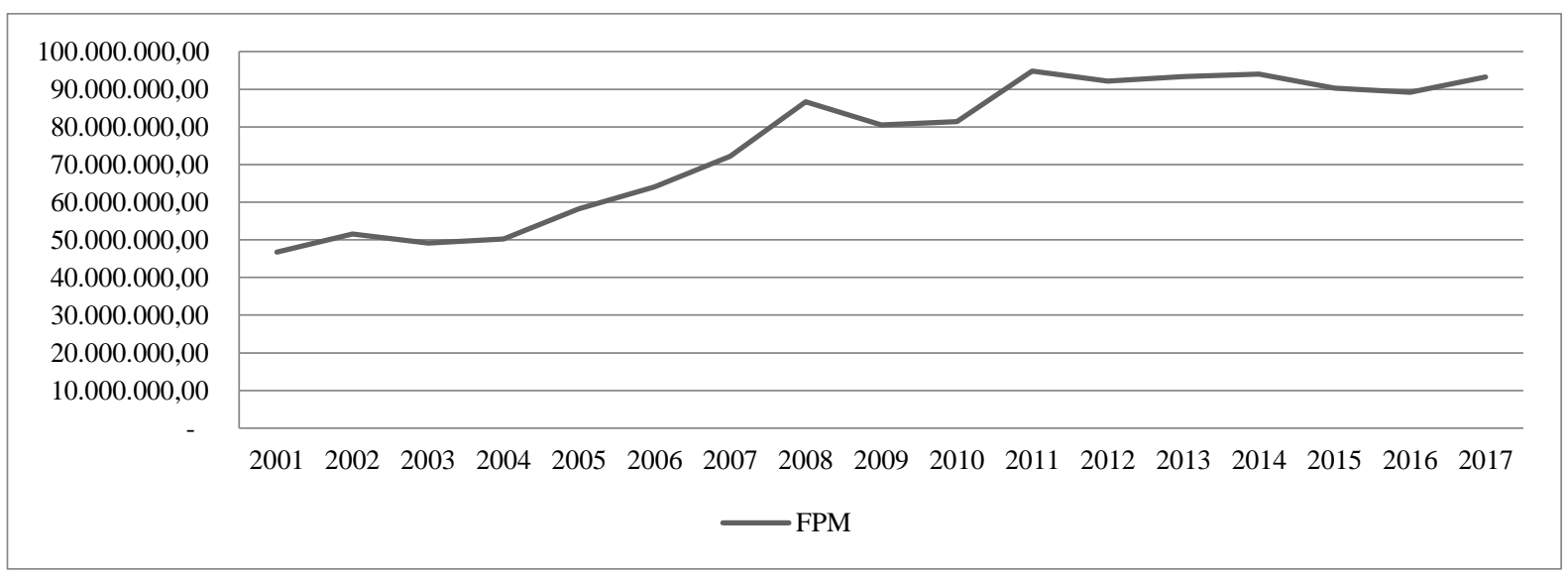

Fonte: FECAM, 2018 - Elaboração: Autores

A importância do FPM está posta por ser o principal tributo em volume de recursos orçamentários repassados aos municípios e que não pode ser contingenciado, é rubrica responsável pela satisfação das principais demandas locais. O FPM tem maior importância para os municípios com menor capacidade de arrecadação própria e de arrecadação do ICMS, por ter um movimento econômico das trocas e de capital de pequeno fluxo na geração de valor. 
O Gráfico 7 apresenta à participação do FPM, deduzido a cota-parte para compor o FUNDEB e o desconto do PASEP, sobre a Receita Corrente Liquida (RCL) de cada município do Alto Vale observando o volume e importância.

O município de Rio do Sul é o maior da região na arrecadação local e teve a menor participação na dependência dos repasses do FPM, 10,76\% da RCL. É o maior município da região em população e possui grandes empresas instaladas no território com link no forte comércio, o que reflete o quantum considerável do repasse de ICMS. Os demais municípios, Taió, Presidente Getúlio, Pouso Redondo Ituporanga e Ibirama o FPM representa entre 25\% e 30\%, a maioria está acima de 30\%. Entretanto, Atalanta, Mirim Doce e Presidente Nereu ultrapassou os $50 \%$.

Com esses indicadores fica evidente o grau de dependência dessa fonte de receita para a existência dos municípios, pois é fundamental para a manutenção da prestação dos serviços necessários à população, e qualquer variação, negativa ou positiva, nesse tipo de repasse tem importante impacto no planejamento orçamentário dos municípios. Agora se observarmos no acumulado veremos que o FPM representou 25,85\% da RCL dos municípios do Alto Vale. Ao confrontar a evolução dos repasses do FPM (líquido) frente aos gastos totais, o resultado indica que em média o FPM cobriu 27,63\% das despesas, deflacionados a valores de 2001 e descontado a cota parte do Fundeb e Pasep. ${ }^{3}$

\footnotetext{
${ }^{3}$ Criado pela Lei Complementar no 8/1970, e por força da Lei Complementar no 26/1975, sofreu unificação com o Programa de Integração social (PIS), dando origem ao Fundo PIS-PASEP. O PASEP é um benefício concedido aos servidores públicos, que equivale ao PIS, oferecido aos empregados da iniciativa privada.
} 
Gráfico 7: FPM (líquido): importância na composição da RCL de cada município do Alto Vale do Itajaí - 2001-2017 (em \%)

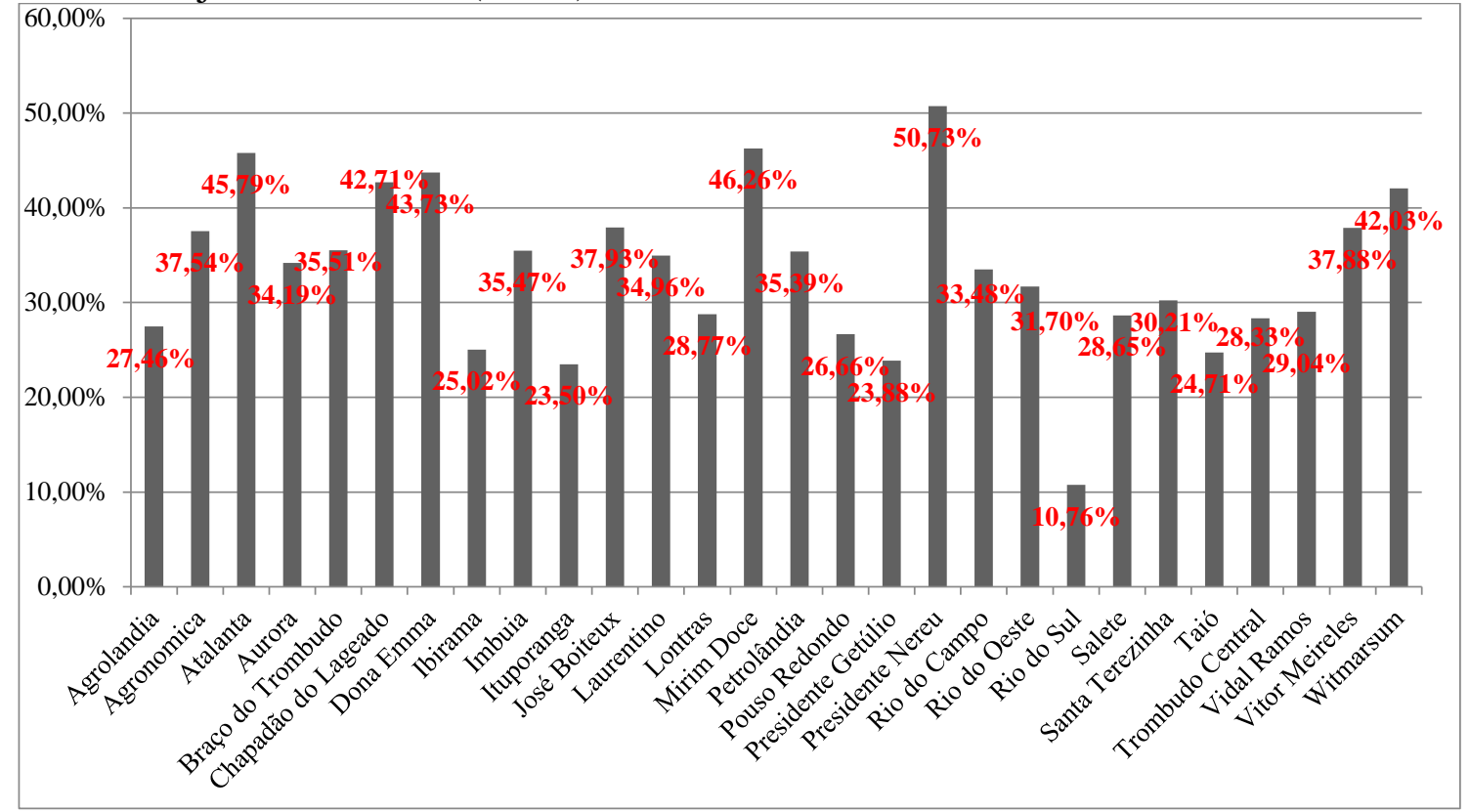

Fonte: FECAM, 2018 - Elaboração: Autores

Entretanto, devido a pequena participação de municípios de pequeno porte na receita total, o aumento de tributos locais não resulta necessariamente em melhorias nas finanças locais, e fica nítido que a linha de evolução dos gastos totais se distanciou da linha do principal repasse do governo federal, Gráfico 8.

Em todos os anos verifica-se que os índices de gastos foram muito superiores dos índices de repasse, com exceção de 2002 em que o índice foi maior do que gastos do Governo. Os gastos totais vêm crescendo mais que o repasse e os recursos do FPM respondem cada vez mais a uma menor fração.

A relação FPM versus gastos totais vem diminuindo ano a ano. Em 2014, o FPM na sua menor significância cobriu em média $22,9 \%$ do total das despesas dos 28 munícipios, e em 2002, a mais significante, essa relação era de 41,2\%.

Além de pressionar pelo aumento dos impostos locais, os municípios se dedicaram a aprimorar a fiscalização dos que são gerados no município, e/ou coletados por outros Entes como o IPVA e o ICMS. Neste contexto, os municípios se veem obrigados a buscar outras fontes de recursos e nisso os gestores acabam "apertando" a comunidade local (IPTU, ISS, ITBI e taxas). Em muitos casos, há redução de obrigações importantes para com a população, como aquisição de medicamentos, materiais de laboratório, uniformes, merenda escolar e mesmo à manutenção do patrimônio e equipamentos públicos. 
Gráfico 8: Evolução dos índices de gastos e repasses do FPM acumulado

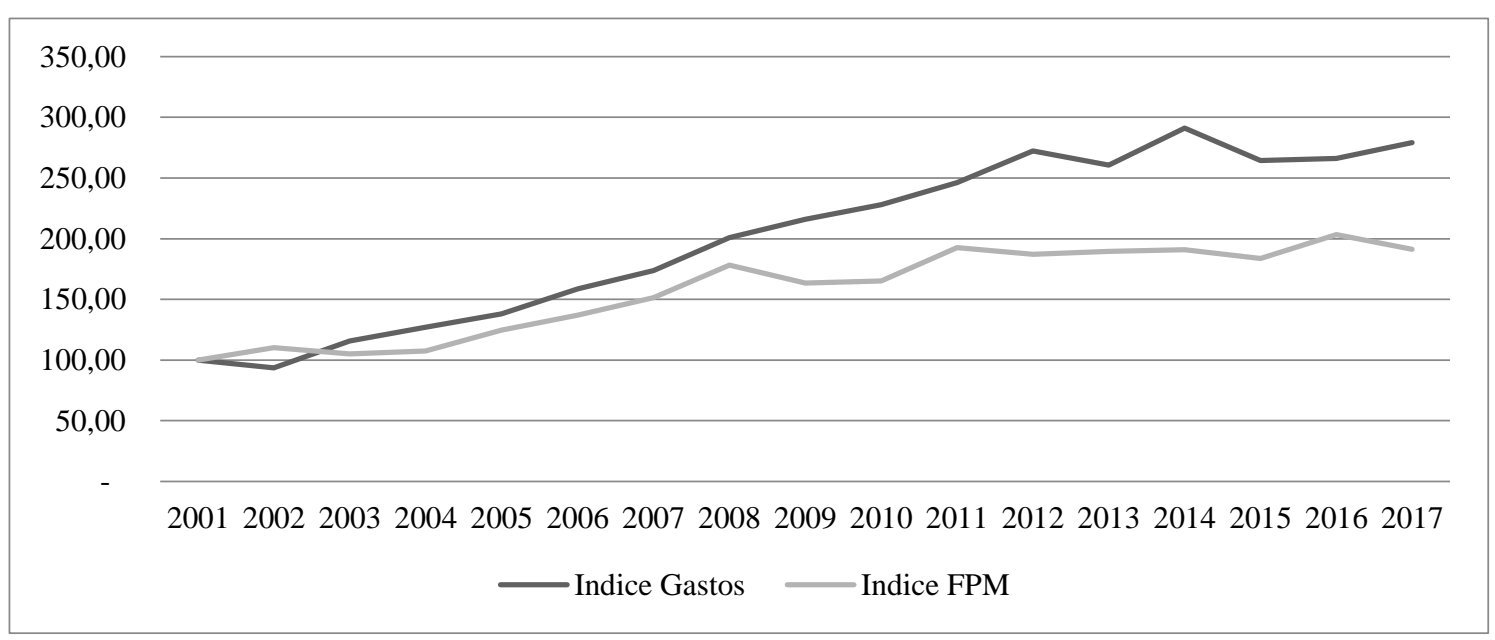

Fonte: TCE/SC e FECAM, 2018 - Elaboração: Autores

O comportamento da arrecadação local demostra os esforços dos gestores em obter outra fonte de arrecadação. Claro está que esse esforço em aumentar a arrecadação local produz impactos políticos negativos aos gestores locais.

Gráfico 9: Comparativo da evolução do FPM da Arrecadação própria e da RCL, deflacionados e em índice de 2001-2017 (2001 = 100)

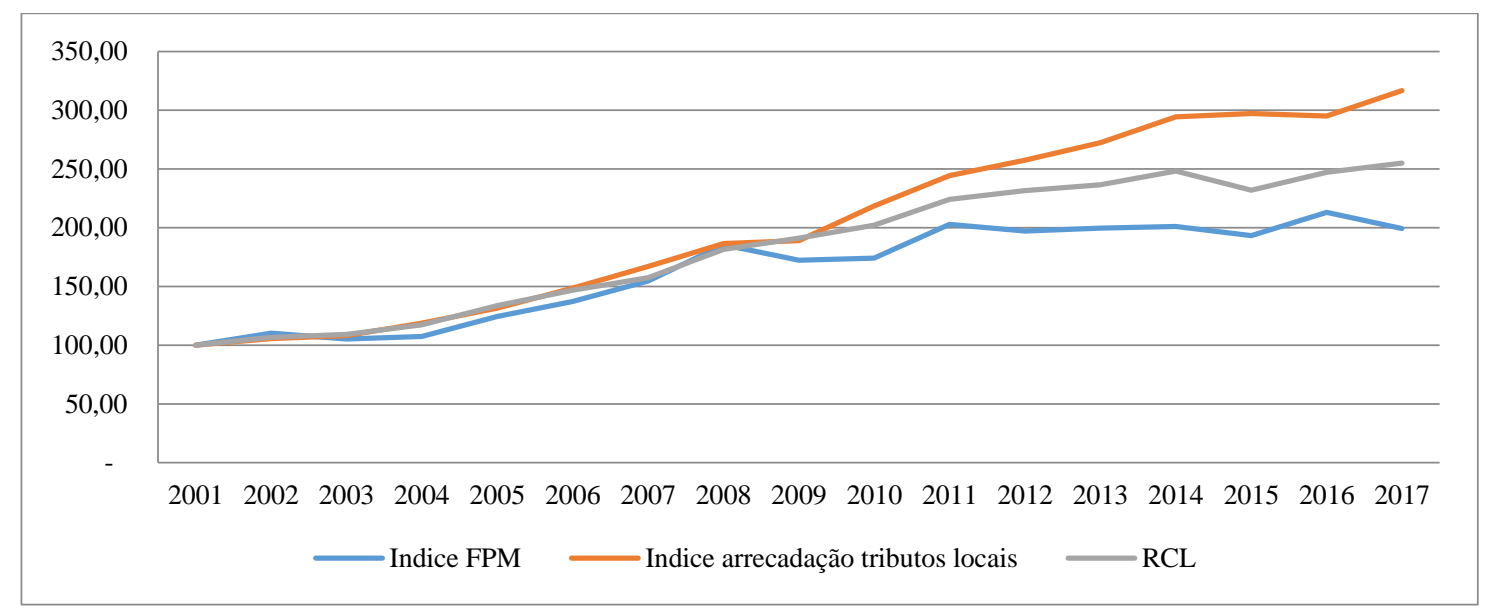

Fonte: TCE/SC e FECAM, 2018 - Elaboração: Autores

O Gráfico 9 mostra que os dos repasses do FPM ficaram abaixo da arrecadação dos tributos locais com crescimento superior partir de 2008, frente à redução em termos reais da principal receita do município de pequeno porte.

Para os 28 municípios do Alto Vale as receitas tributárias representaram cerca de $11,70 \%$ do total arrecadado, mas todos os municípios possuem como principal fonte de 
receitas as Transferências Correntes da União 42,13\% e do Estado/SC com 25,89\%, Gráfico 10.

Gráfico 10: Receitas de transferências do Estado/SC e União e o volume de arrecadação Local entre 2001 e 2017 (em \%/Total)

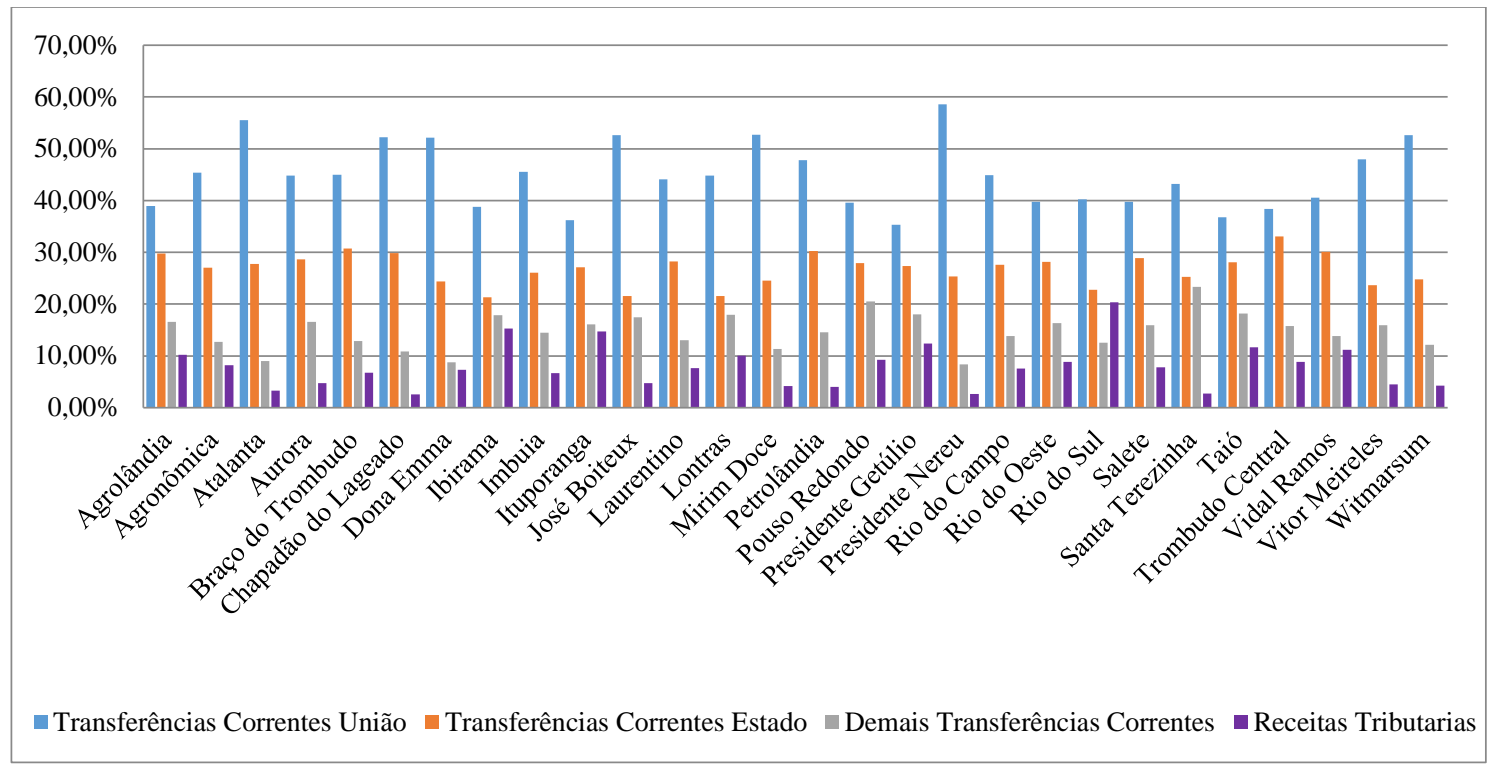

Fonte: TCE/SC, 2018 - Elaboração: Autores

O destaque fica por conta dos municípios em que a arrecadação proveniente dos tributos locais apresenta maior importância, tais como Rio do Sul (20,32\%), Ibirama $(15,28 \%)$ e Ituporanga $(14,75 \%)$. Nos demais municípios a arrecadação local acumulada ficou abaixo dos $12,0 \%$ do total, tendo casos em que essa participação foi menor que 3,0\%.

Os recursos para a execução de vários programas do Governo federal repassados às prefeituras para custeá-los, tornam-se cada vez mais insuficientes. Conforme estimativa realizada pela FECAM (2017), na área de educação os municípios catarinenses assumiram cerca de 51,0\% do custeio do PNAE para alimentação em 2014.

O mesmo ocorreu na área da saúde com o Programa de Estratégia da Saúde da Família (PESF), em que 60,0\% do custeio ficou com os municípios e a União com $40 \%$ restantes. Situação semelhante se encontra nos programas Farmácia Básica, Saúde Bucal, SAMU e Programa de Agentes Comunitários de Saúde (PACS), conforme o Gráfico 11. 
Gráfico 11: Custeio de programas federais (2014)

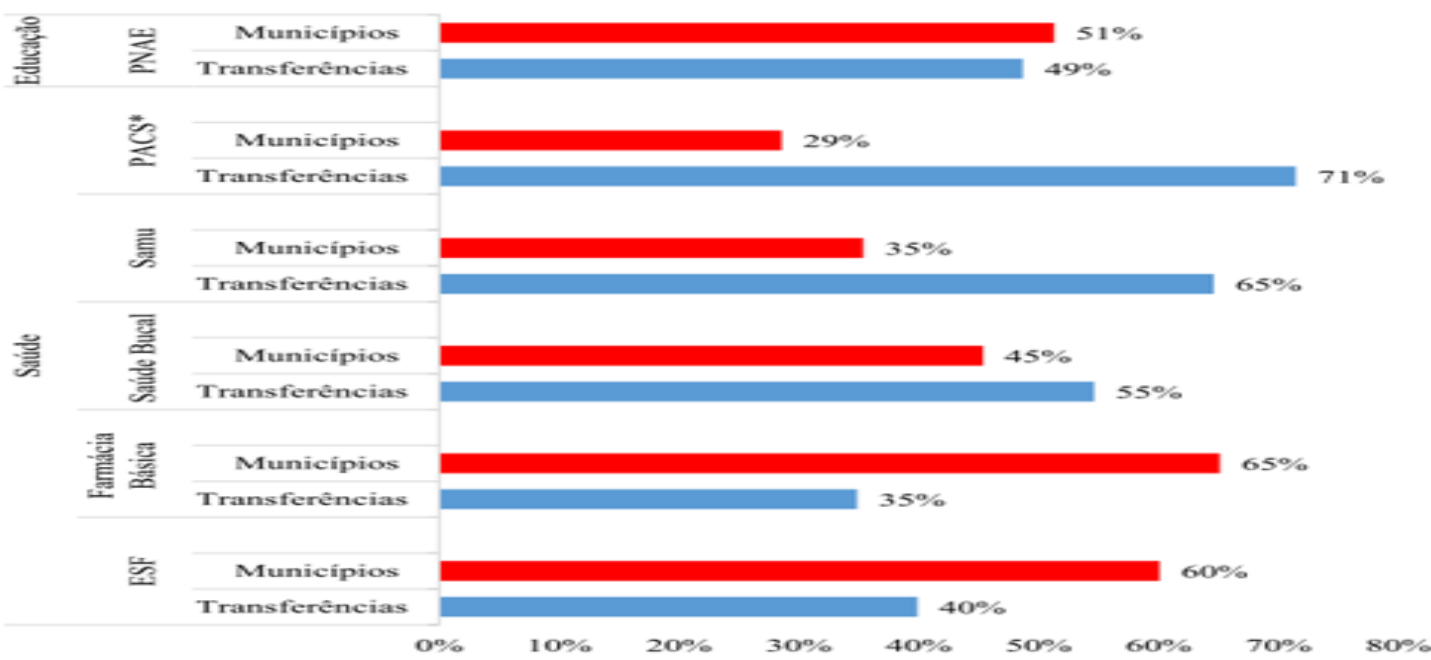

Fonte: Portal de Transparência, 2016; FECAM, 2018 - Elaboração: Autores

Outra fonte, de custo adicional, consiste no reajuste do Salário Mínimo Nacional (SMN) em que reflete a correção dos pisos salariais dos servidores públicos em que a situação se agrava muitas vezes, principalmente quando os reajustes são superiores à inflação e à expansão da arrecadação dos municípios.

Há, por outro lado, condicionalidades constitucionais em áreas com rubricas da repartição anual constitui cumprimento das obrigações a atender os limites instituídos pela LRF/2000 nas áreas da Educação (25\%) e da Saúde (15\%).

Gráfico 12: Média dos índices de gastos com educação: municípios do Alto Vale do Itajaí (2001-2017)

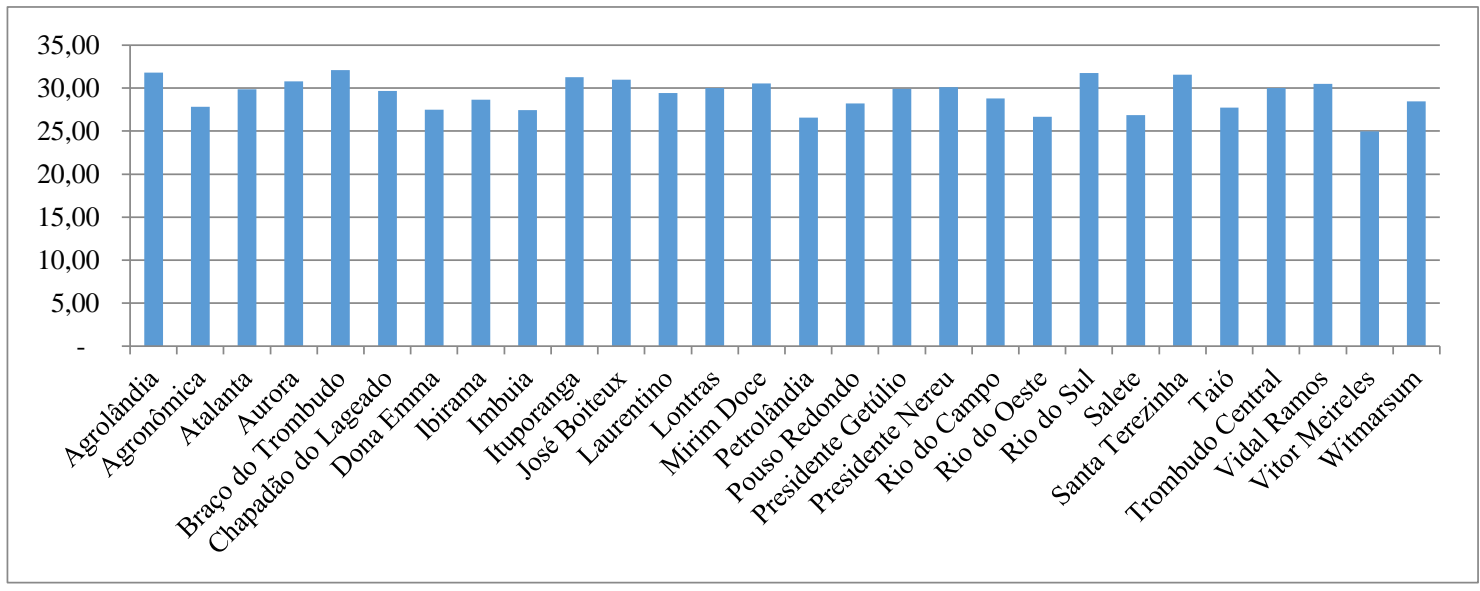

Fonte: TCE/SC, 2018 - Elaboração: Autores 
No geral, com exceção de Vitor Meireles, todos os municípios cumpriram com suas obrigações previstas na CF/88, artigo 212. Gráfico 12: Educação (29,29\%), Saúde (18,28\%). O restante $(52,43 \%)$ é aplicado em outras rubricas: investimentos, assistência social, fiscalizações, política econômica, agricultura, turismo, pesca, esporte, políticas de prevenção e combate às drogas, segurança, iluminação pública, saneamento, demais manutenções, cumprindo assim as obrigações legais.

Gráfico 13: Média dos índices de gastos com saúde dos municípios do Alto Vale do Itajaí (2001- 2017)

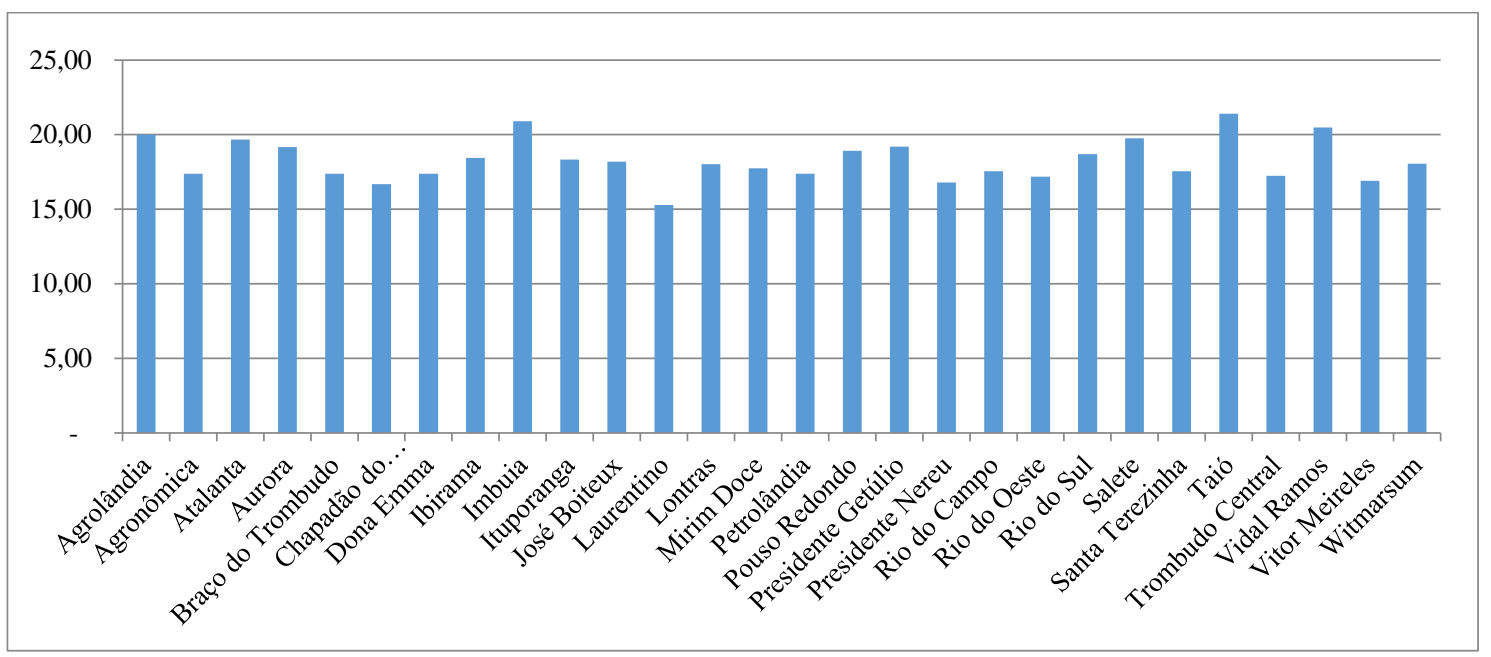

Fonte: TCE/SC, 2018 - Elaboração: Autores

Considerando o limite mínimo de gastos com Saúde e todos os municípios cumpriram com o disposto no artigo 77, III c/c $\S 4^{\circ}$, do Ato das Disposições Constitucionais Transitórias (ADCT). Gráfico 13.

Do Orçamento municipal, o gasto com a Folha de pagamento do Poder Executivo não pode ultrapassar 54\%, e para o Legislativo 6,0\%. Entretanto, o Tribunal de Contas do Estado (TCE/SC) emite um aviso de "limite prudencial" quando este índice atinge 51,3\%. A partir daí o gestor necessita adotar uma série de medidas para que o índice não atinja o limite de $54,0 \%$.

E média os municípios atenderam as obrigações com pessoal até 2014. No ano seguinte muitos municípios superaram o limite prudencial e até mesmo o limite máximo. Em 2016 a média dos gastos com pessoal ficou de 52,61\%, cai para 50,63\% em 2017.

Em momentos de crise os gestores normalmente ajustam as despesas com os primeiros cortes nos investimentos. Nota-se que a despesa de capital foi muito inferior às 
despesas correntes, e para compensar, o percentual das despesas de capital caiu em relação às despesas correntes, assinalando a baixa capacidade de investimento dos municípios.

Gráfico 14: Evolução da despesa com pessoal: executivo e legislativo (2001-2017)

\begin{tabular}{|c|c|c|c|c|c|c|c|c|c|c|}
\hline \multicolumn{11}{|c|}{ Evolução das Despesas com Pessoal } \\
\hline \multirow{2}{*}{50,00} & & \multirow{2}{*}{43,66} & \multirow{2}{*}{44,48} & \multirow{2}{*}{44,64} & \multirow[t]{2}{*}{48,98} & 49,75 & 50,56 & 52,61 & 48,59 & 50,63 \\
\hline & 39,37 & & & & & & & & & \\
\hline 30,00 & & & & & & & & & & \\
\hline 20,00 & & & & & & & & & & \\
\hline 10,00 & 2,34 & 2,99 & 2,79 & 4,36 & 2,64 & 3,01 & 2,97 & 3,11 & 3,06 & 3,04 \\
\hline & 2008 & 2009 & 2010 & 2011 & 2012 & 2013 & 2014 & 2015 & 2016 & 2017 \\
\hline
\end{tabular}

Fonte: TCE/SC, 2018 - Elaboração: Autores

Destaca-se que em virtude da crise econômica nos anos de 2015 a 2017, o percentual do investimento na receita corrente líquida foi menor que nos demais anos. Entretanto, a situação é ainda pior, pois ficou em média 5,0\% da receita corrente liquida em despesas de capital, ao descontar as receitas de capital como transferidas aos municípios exclusivamente para investimentos públicos. Gráfico 15.

Gráfico 15: Despesas correntes e de capital (em \%/Total)

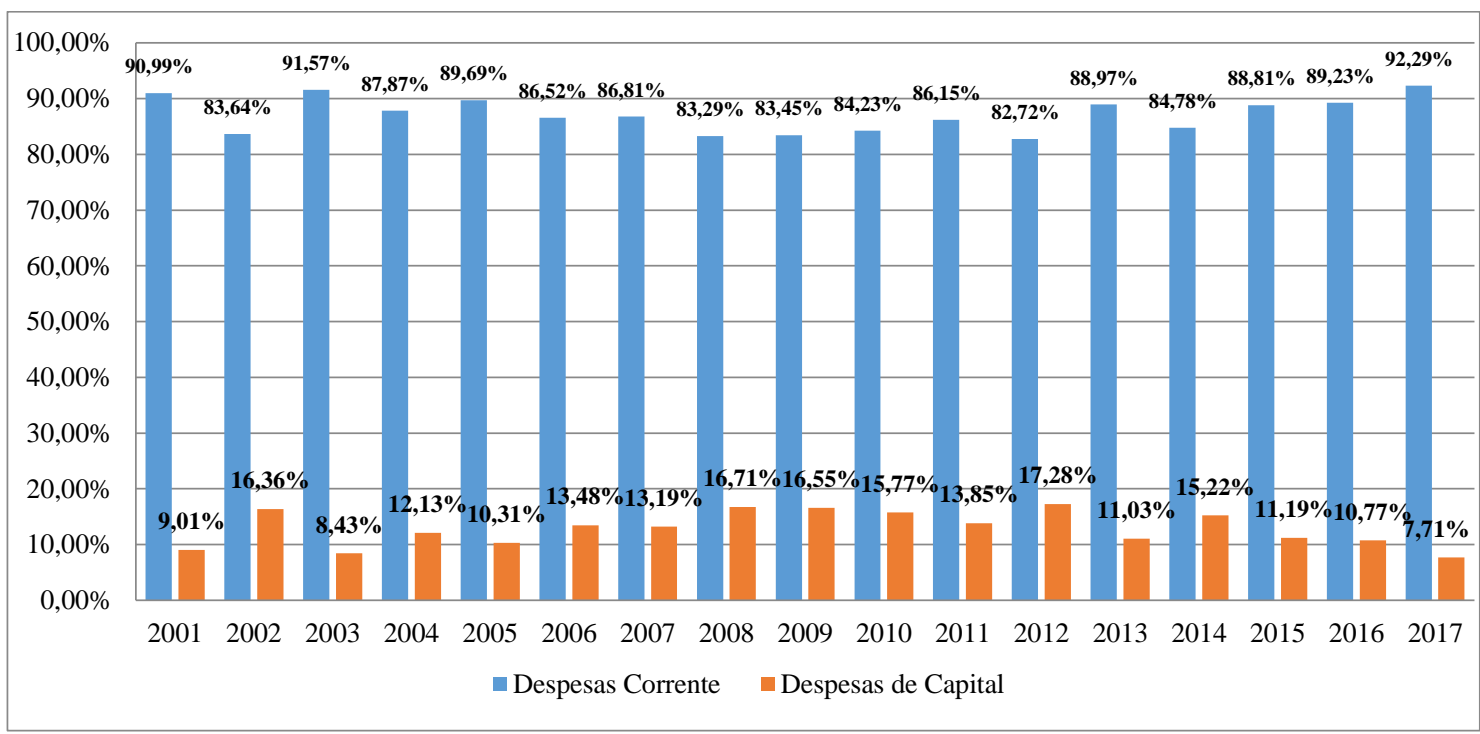

Fonte: TCE/SC, 2018 - Elaboração: Autores 
Os resultados, no geral, demostram as evidências da dependência das receitas orçamentárias dos municípios através dos repasses nas transferências correntes da União e do Estado/SC, comprometendo sobremaneira os recursos disponíveis.

As condicionalidades, interpostas aos Entes, reduz a porção orçamentária dos recursos a ser de livre aplicação pelos gestores. Nestes casos, apesar dos esforços dos gestores para aumentar a arrecadação local, este estudo apresenta como resultado concreto o aumento na dependência orçamentária através das transferências constitucionais, uma vez que fica evidente a situação crítica gerada por reflexos fiscais negativos nas determinações do investimento público em geral.

A qualidade na aplicação do dinheiro público como recurso essencial a satisfação das necessidades sociais, a expansão da demanda por bens e serviços públicos e dificuldades frente às abruptas variações na arrecadação, afetam diretamente os índices de repasses e a quantidade dos recursos necessários, o que impede melhorias da atuação frente aos desafios dos projetos de desenvolvimento e sustentabilidade das cidades e regiões metropolitanas.

\section{Considerações finais}

Há que se considerar como visíveis e inquestionáveis as dificuldades orçamentárias na gestão municipal. Ressalte-se que o processo de descentralização foi ineficiente e a relativa autonomia política e financeira vigente contribuiu minimamente para a redução das desigualdades sociais e territoriais.

Destacou-se o fato de que a instituição da LRF/2000 cria exigência de cláusula de condicionalidade, determinando adimplência em obrigação financeira ou contratual assumidas pelos Entes.

Esta condição gera enormes benefícios ao desenvolvimento do setor financeiro em detrimento das necessidades do financiamento público e da seguridade social, pois, claro está demonstrado os mecanismos e dispositivos do sistema da dívida pública que a Auditoria Cidadã vem denunciando a décadas, apresenta-se a situação crítica da repartição dos recursos orçamentários, um dos fundamentos da desigualdade na divisão do bolo orçamentário, pois dos R \$ 2,6 trilhões do orçamento executado em 2018, 40,7\% foram para pagamento de juros e amortizações da dívida, contra os 39,7\% de 2017. 
Em contrapartida, como condição essencial para a expansão das receitas próprias, os gestores necessitam planejar de forma eficiente a expansão das receitas, a melhoria na qualidade dos gastos e investimentos e eficácia na captação de recursos novos.

A análise desta situação crítica da centralização e concentração dos repasses constitucionais nos leva a conclusão óbvia pela necessidade de ajustes estruturais quanto as transferências correntes.

Como se verificou aqui há propostas concretas em pauta, merecendo ampliação do debate sobre a política de repartição orçamentária. Um bom ponto de partida é a proposta da FECAM: União reteria 45,0\%, os Municípios 30,0\% e os Estados subnacionais 25,0\%. Nestas proporções, por si só, melhoraria imenso os recursos suficientes para a gestão pública dos Entes federados brasileiros.

\section{Referências}

ARAÚJO, J. C.; PEREIRA JUNIOR, J. S.; PEREIRA, L. S.; RODRIGUES, J. P. Ensaios sobre impactos da Constituição Federal de 1988 na sociedade brasileira. Brasília: Edições Câmara, 2008, 2v., (Câmara dos Deputados, Série coleções especiais, obras comemorativas; n. 2), 1005 p.

AMAVI - ASSOCIAÇÃO DOS MUNICÍPIOS DO ALTO VALE DO ITAJAÍ. Disponível em: https://www.amavi.org.br/. Acesso em: 05 ago. 2017.

\section{AMAVI - ASSOCIAÇÃO DOS MUNICÍPIOS DO ALTO VALE DO ITAJAÍ. Estatuto da Associação dos Municípios do Alto Vale do Itajaí. Rio do Sul: Amavi, 2007.}

BORGES, F. C. Origens históricas da propriedade da terra - 1958. In. STEDILE. J. P. (Org.). A questão agrária no Brasil: o debate tradicional - 1500-1960. 1 ed. São Paulo: Expressão Popular, 2005, p. 259-281.

BRASIL. Ministério da Fazenda/Tesouro Nacional. http://www.tesouro.fazenda.gov.br/contabilidade_governamental/execucao_orcamentari a_do_GF/Consolidacao_Contas_Publicas.xls. Acesso em: 01 jun. 2018b.

BRASIL. Ministério da Fazenda/Tesouro Nacional. Item 1.6. Demonstrativo da dívida consolidada líquida - DCL. Revisão do Capítulo do Demonstrativo da Dívida Consolidada - DCL no Manual de Demonstrativos Fiscais - MDF (Material de Discussão). Disponível em: http://www.tesouro.fazenda.gov.br/documents/10180/434322/CPU_1.6_Demonstrativo _DCL.pdf/c216a18d-f0e7-4073-b771-14d92058a9c4. Acesso em: 01 jun. 2018a.

BRASIL. Constituição da República Federativa do Brasil. 19 ed. Brasília: Câmara dos Deputados, Coordenação de Publicações, 2002. (Texto constitucional de 5 de outubro de 
1988, com as alterações adotadas pelas Emendas Constitucionais de n. 1, de 1992, a 38, de 2002, e pelas Emendas Constitucionais de Revisão de n. 1 a 6, de 1994).

BRASIL. Lei Complementar $n^{0}$ 101, de 4 de maio de 2000. Estabelece normas de finanças públicas voltadas para a responsabilidade na gestão fiscal e dá outras providências. Disponível em: http://www.planalto.gov.br/ccivil_03/Leis/lcp/Lcp101.htm. Acesso em: 30 mai. 2018.

BRASIL. Portal de Transparência. Controladoria-geral da União. Disponível em: http://www.portaltransparencia.gov.br/. Acesso em 20 nov. de 2016.

CANZIAN, F. $70 \%$ dos municípios dependem em mais de $80 \%$ de verbas externas. Disponível em: http://temas.folha.uol.com.br/remf/ranking-de-eficiencia-dosmunicipios-folha/70-dos-municipios-dependem-em-mais-de-80-de-verbasexternas.shtml Acesso em: 08 fev. 2019.

CNM - CONFEDERAÇÃO NACIONAL DE MUNICÍPIOS. A crise dos municípios brasileiros. Brasília, DF 2017.

CNM - CONFEDERAÇÃO NACIONAL DE MUNICÍPIOS. FPM de 2016 foi salvo pelos recursos da repatriação. Brasília: $\mathrm{Cnm}$, fev. 2017. 12 p. Disponível em: http://www.cnm.org.br/biblioteca/download/2760. Acesso em: 07 jun. 2017.

CNM - CONFEDERAÇÃO NACIONAL DE MUNICÍPIOS. Vitoria municipalista: parlamentares derrubam veto ISS e garantem R\$ 6 bi aos cofres municipais. Brasília: Cnm, jun. 2017. 20 p. Disponível em: http://www.cnm.org.br/biblioteca/download/2885. Acesso em: 02 jul. 2017.

CNM - CONFEDERAÇÃO NACIONAL DE MUNICÍPIOS. Viva seu município. Disponível em: http://www.vivaseumunicipio.cnm.org.br/panorama.php. Acesso em: 25 out. 2017.

COURI, D. V.; BIJOS, P. R. S. Breve análise sobre a PEC 241/2016, que altera o ato das disposições constitucionais transitórias para instituir o novo regime fiscal. Orçamento em Discussão n. 26. Senado Federal, Brasília, DF. (Consultoria de Orçamentos, Fiscalização e Controle - CONORF). Disponível em: http://www2.senado.leg.br/bdsf/bitstream/handle/id/521801/OED0026.pdf? sequence=1. Acesso em: 12 fev. 2017.

ESPINDOLA, M. J. Crise nas contas públicas: uma análise para os municípios de pequeno e médio porte do Alto Vale do Itajaí. Florianópolis, 2017. 144f. Monografia (Graduação/EaD) - Universidade Federal de Santa Catarina, Centro Socioeconômico, 2017.

FATORELLI, M. L. Auditoria cidadã da dívida dos Estados. Editora Inove, Brasília. FATORELli, M. L. O sistema da dívida no Brasil e no mundo. Disponível em: https://www.auditoriacidada.org.br/wp-content/uploads/2014/10/USP-14-10-2014-OSistema-da-Divida-no-Brasil-e-no-Mundo.pdf. Acesso em 05 mar. 2018. 
FECAM - FEDERAÇÃO CATARINENSE DE MUNICÍPIOS. Calamidade financeira: manifesto sobre a crise financeira e econômica em defesas dos municípios catarinenses. Florianópolis: FECAM, 2017.

FECAM - FEDERAÇÃO CATARINENSE DE MUNICÍPIOS. https://www.fecam.org.br/catalogo/index/index/codCatalogoItem/6. Acesso em: 08 jan. 2019.

MONTALVÃO, R. Especial: há 30 anos, Constituição Federal incluiu o município entre os entes federados. Disponível em: https://www.cnm.org.br/comunicacao/noticias/especial-ha-30-anos-constituicao-federalincluiu-o-municipio-entre-os-entes-federados. Acesso em 10 out. 2018.

GOMES, L. S. Repasse de recursos: convênio ou transferência fundo a fundo? Brasília: Senado Federal, 2013. Orçamento Público em discussão n. 08 (Consultoria de Orçamentos, Fiscalização e Controle). Disponível em: https://www12.senado.leg.br/orcamento/documentos/estudos/tipos-deestudos/orcamento-em-discussao/edicao-8-2013-repasse-de-recursos-convenio-outransferencia-fundo-a-fundo. Acesso em 09 nov. 2018.

IBGE - INSTITUTO BRASILEIRO DE GEOGRAFIA E ESTATÍSTICA. Disponível em:

http://www.ibge.gov.br/home/estatistica/economia/despesaspublicas/financaspublicas_2 003/default.shtm. Acesso em: 17 mai. 2018.

MARX, K. Para a crítica da economia política. São Paulo: Abril Cultural, 1982. PIAZZA, W. F. Santa Catarina: sua história. Florianópolis: UFSC/Lunardelli, 1983. TESOURO NACIONAL. Disponível em: http://www.tesouro.fazenda.gov.br/contabilidade_governamental/execucao_orcamentari a_do_GF/Consolidacao_Contas_Publicas.xls. Acesso em: 17 mai. 2018.

TCE/SC - TRIBUNAL DE CONTAS DO ESTADO DE SANTA CATARINA Disponível: http://www.tce.sc.gov.br/transparencia-acesso-a-informacao. Acesso em: 18 dez. 2018.

VEDANA, C. Federalismo: autonomia tributária formal dos municípios. Florianópolis: Habitus, 2002. 208 p. 